\title{
Tüketicilerin Online Alışveriş̧lerindeki Sanal Kart Kullanımlarının Teknoloji Kabul Modeli İle İncelenmesi
}

\author{
Investigation of Consumers' Virtual Card Use in their Online Shopping \\ with Technology Acceptance Model
}

\author{
Dr. Öğr. Üyesi Selma KALYONCUOĞLU ${ }^{1}$
}

\begin{abstract}
Özet
1980'li yıllarla başlayan ve halen devam eden küreselleşmenin dördüncü dönemi ile bilgi ve iletişim alanındaki teknolojik ilerlemeler bilgisayar ve internet kullanımı üzerinde de kayda değer etkiler oluşturmuştur. Tüketicilerin internet üzerinden mal ve hizmet satın alma eğilimindeki artış, online alışverişlerde güvenli ödeme sistemi oluşturulması gereksinimini ortaya çıkarmıştır. Bu kapsamda, tüketicilerin online alışverişleri için güvenilir bir bankacılık ürünü olan sanal kart uygulamasının önemi ortaya çıkmış ve sanal karta yönelik tüketici algılarının, araştırma konusu olarak ele alınması gerekliliği öne çıkmıştır. Tüketicilerin online alışverişlerinde ödeme işlemlerinin güvenilirliği için sanal kart kullanımlarının kabulünü etkileyen faktörler Teknoloji Kabul Modeli ile incelenmiştir. Online alışverişlerinde sanal kart kullanan 490 tüketiciye ulaşılan çalışmada, sanal kart kullanımının kabulünü açıklamada Yapısal Eşitlik Modeli (YEM) kullanılmıştır. Araştırma sonuçları, gerçekleşen davranış (online alışverişlerinde sanal kart kullanımı) açısından; tüketicinin algılanan fayda, algılanan kullanım kolaylığı, tutum ve davranışsal niyet düzeyinin önemli belirleyici etkileri olduğunu ortaya koymaktadır.
\end{abstract}

Anahtar Kelimeler: Teknoloji kabul modeli, sanal kart, yapısal eşitlik modeli

\begin{abstract}
Technological advances in the field of information and communications have created a significant impact on the use of computers and internet within the fourth period of globalization which started in 1980s and still continues to progress. The increase in consumers' tendencies towards buying goods and services on internet has required the establishment of secure payment systems in online shopping. Within this regards, the importance of Virtual Card which is a reliable banking product for consumers in online shopping has emerged, and it has become a necessity to address consumers' perception towards Virtual Card as a research topic. Factors which affect the acceptance of consumers' use of Virtual Card in their online shopping with the intent of security of payment procedures have been investigated within the framework of Technology Acceptance Model. 490 consumers who use Virtual Card in their online shopping were reached in the study, and Structural Equation Modelling has been applied to explain the acceptance of Virtual Card use. The results of the study reveal that perceived usefulness, perceived ease of use, and attitude and behavioural intention levels of consumers have determining effects in terms of actual system use (use of Virtual Card in online shopping).
\end{abstract}

Keywords: Technology acceptance model, virtual card, structural equation modelling

\footnotetext{
${ }^{1}$ Gazi Üniversitesi, İktisadi ve İdari Bilimler Fakültesi, selmakalyoncuoglu @ gmail.com, Orcid ID: orcid.org/0000-0003-47457836
} 


\section{Giriş}

Son y1llarda bilgi ve iletişim teknolojileri alanında yaşanan hızlı gelişmeler ve değişimler teknoloji uygulamalarındaki çeşitliliği beraberinde getirmiştir. İtici güç niteliğinde bulunan bilgisayar ve internet teknolojilerindeki değişimler, birçok faaliyetin dijital olarak yapılmasına ve sürdürülmesine imkân sağlamış; böylelikle fiziksel olarak gerçekleştirilen birçok faaliyet online mecralara da taşınmıştır. Bu kapsamda alıcı ile satıcı fiziksel olarak bir araya gelmeden de mallar/hizmetler alınıp satılabilir hale gelmiş ve elektronik pazarlar ortaya çıkmıştır. Böylelikle internet üzerinden yapılan alışverişler, bireyler için vazgeçilmez bir nitelik kazanmıştır.

2017 y1lı dördüncü üç aylık dönem (Ekim-Kasım-Aralık) sonu itibariyle Türkiye'de internet abone kullanıcı sayısının 68,9 milyona ulaştı̆̆ (Bilgi Teknolojileri ve İletişim Kurumu (BTK), 2017 Pazar Verileri Raporu) göz önünde bulundurulduğunda; tüketicilerin alışveriş yapma kalıplarının değiştiği ve internetten alışverişin kabul görme hızının ve yaygınlığının tüketicilerin hayatlarını kolaylaştırması nedeniyle arttığı ifade edilebilir. Tüketicilerin internetten mal ve hizmet satın alımlarındaki bu artış, online alışverişlerde güvenli ödeme yapabilme gereksinimini ortaya çıkarmış ve güvenilir bir bankacılık ürünü olan sanal kartların kullanımının yaygınlaşmasını beraberinde getirmiştir.

Sanal kartlar; tüketicilerin internet üzerinden güvenle alışveriş yapabilmeleri için ası1 kredi kartı bilgilerini paylaşmadan, ihtiyacı kadar olan limiti, asıl kredi kartlarından sanal kartlara aktararak risksiz bir şekilde ödeme yapılmasını sağlayan bir üründür. Son yıllarda tüketicilerin bilinçlendiği ve internetten güvenli alışveriş yapabilmek için bir ileri teknoloji ürünü olan sanal kart kullanımlarının ciddi düzeylerde ivmelendiği göz önünde bulundurulduğunda; tüketicilerin sanal kart kullanma davranışını etkileyen faktörlerin belirlenerek; hem kart çıkaran kuruluşlara hem de üye iş yerlerine yol gösterici olmak büyük önem taşımaktadır.

Bilgi teknolojilerinin bireyler tarafından kullanımlarına ilişkin alan yazında birçok teori olmakla birlikte yetkinliğini ve geçerliliğini teorik ve deneysel şekilde kanıtlamış olması (Davis, Bagozzi ve Warshaw, 1989: 983) hasebiyle; teknolojiyi kullanma ve benimseme davranışlarını içeren ve Davis (1985) tarafından geliştirilen Teknoloji Kabul Modeli (TKM), en çok kullanılan teorilerden birisi olmuştur. İnsanların teknoloji kullanımına olan direncini belirlemek, teknoloji kabulünün nedenlerini anlamak, kullanıcıların yenilik ve değişikliklere verecekleri cevapları tahmin etmek ve sistemdeki değişmeyle gerçek kullanımdaki gelişmeyi incelemek amacıyla kullanılan TKM, teknolojinin kullanıldığı çoğu vakada, teknoloji ile uyumu açıklamada yeterli kabul edilmektedir (Vijayasarathy, 2004: 748; Davis, 1989: 333-334; Adams, Nelson ve Tood, 1992: 245).

Teknoloji Kabul Modeli'nin bilgi teknolojileri açısından kabulü, alan yazında birçok farklı çalışmayla ele alınmıştır. Öyle ki; muhasebede bilgi teknolojisi kullanımı (Özer, Özcan ve Aktaş, 2010), internet bankacılığı kullanımı (Munoz-Leiva, Climent-Climent ve LiebanaCabanillas, 2017; Ceylan, Genç ve Erem, 2013; Ustasüleyman ve Eyüboğlu, 2010; Lee, 2009), mobil internet kullanımı (Şıklar, Tunalı ve Gülcan, 2015), elektronik ve mobil kütüphane hizmetlerinin kullanımı (Yoon, 2016; Jeong, 2011; Kurulgan ve Özata, 2010), insan kaynakları bilgi sistemlerinin kullanımı (Aras, Özdemir ve Bayraktaroğlu, 2015), 
karekodların kullanımı (Kim ve Woo, 2016; Tüfekci, 2014), internet üzerinden alışveriş yapma (Wu ve Liao, 2011; Ha ve Stoel, 2009; Y1lmaz ve Tümtürk, 2015; Çelik, Y1lmaz ve Pazarlığlu, 2010; Turan, 2008), e-açık eksiltme teknolojisinin kullanımı (Gümüşsoy ve Çalışır, 2009) ile mobil uygulamaların kullanımına (Uğur ve Turan, 2016) mesnet olan birçok çalışmada bireylerin ilgili teknolojileri kullanma ve benimseme niyetleri TKM ekseninden değerlendirilmiştir. Ancak tüketicilerin online alışverişlerini güvenle yapabilmelerine imkan sağlayan bir ödeme sistemi olan sanal kartı kabul etme ve kullanma davranışını TKM ile açıklayan bir çalışmaya rastlanmamıştır. Bu ihtiyaçtan yola çıkarak çalışmanın amacı, internetten güvenli alışveriş yapabilmek için geliştirilmiş bir uygulama olan sanal kartın kabulüne ve benimsenmesine yönelik gerçekleşen davranışı etkileyen faktörleri ortaya koymaktır. Dolayısıyla çalışma kapsamında; algılanan fayda ve algılanan kullanım kolaylığının tüketicilerin sanal kart kullanımlarına ilişkin tutumlarına, tutumlarının sanal kartı kullanıma devam etme niyetlerine ve niyetlerinin de sanal kartı kullanma davranışlarına olan etkisi, oluşturulan araştırma modeli dâhilinde incelenmektedir. Tüketicilerin online alışverişlerini güvenle yapmalarına destek verecek bir bilgi sistemi olan sanal kartların kullanımlarını etkileyen faktörleri incelemek üzere kurulan araştırma modeline dayanılarak oluşturulan hipotezlerin test edilmesiyle kavramlar arasındaki ilişkiler analiz edilmiştir. Elde edilen bulgular çerçevesinde çalışmanın hem literatüre hem de sektör uygulayıcılarına katkı vermesi amaçlanmaktadır. Ayrıca sunulacak önerilerin de gelecekte yapılacak çalışmalara katkı sağlayacağı düşünülmektedir.

\section{Kuramsal Çerçeve}

\subsection{Teknoloji Kabul Modeli}

Bilgi sistemlerinin kullanımını ve kabulünü açıklayan Teknoloji Kabul Modeli (TKM), Davis (1985) tarafından geliştirilmiştir. Akademi dünyasındaki araştırmacılar tarafindan en s1k kullanılan model olan TKM (Venkatesh, 2000: 343), Fishbein ve Ajzen tarafindan 1975 y1lında geliştirilmiş olan Sebepli Eylem Teorisi (SET) üzerine temellenmiştir (Davis, Bagozzi ve Warshaw, 1989: 985; King ve He, 2006: 740).

Bilinçli olarak istenilen davranışların belirleyicileriyle ilgilenen sosyal psikoloji alanında SET kullanılarak yapılan çokça çalışma mevcuttur. Sebepli Eylem Teorisi'ne göre bir kişinin belirli bir davranıştaki performansı, davranışını gerçekleştirmeye yönelik davranışsal niyetiyle belirlenirken; davranışsal niyet de kişinin tutum ve öznel normu tarafindan ortaklaşa belirlenmektedir (Davis, Bagozzi ve Warshaw, 1989: 983). Her ne kadar SET modelinde öznel normlar yer alsa da, belirsiz teorik ve psikometrik durumu nedeniyle öznel normlar, SET modelinden uyarlanan TKM'ye dâhil edilmemiştir (Davis, Bagozzi ve Warshaw, 1989: 986).

Kişilerin bilgi sistemlerini kabul etme ve kullanma niyetlerini tahmin etmek amacıyla yaygın bir şekilde kullanılan Teknoloji Kabul Modeli; dışsal değişkenler, algılanan fayda, algılanan kullanım kolaylığı, kullanıma yönelik tutum, davranışsal kullanım niyeti ve gerçekleşen kullanım arasındaki nedensel ilişkilere dayanarak bilgi teknolojileri kullanıcılarının hareketlerini açıklayan bir model olarak Şekil 1'de gösterilmektedir: 
Şekil 1. Teknoloji Kabul Modeli (TKM)

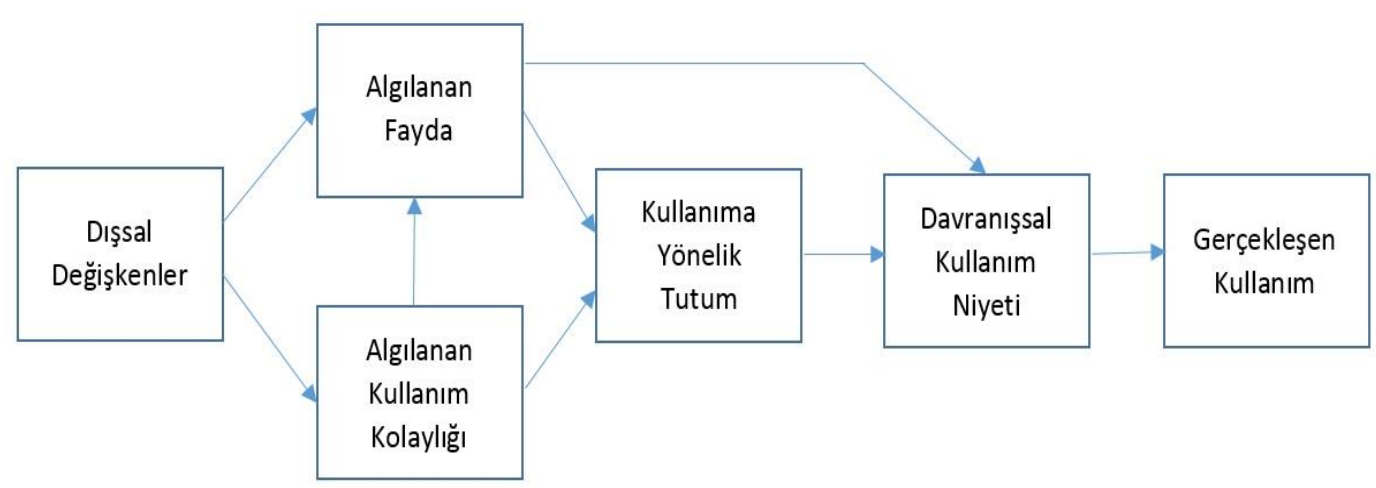

Kaynak: Davis, Bagozzi ve Warshaw, 1989: 985.

Teknoloji kullanımının gerçekleşmesini altı temel unsura dayandırarak ölçmeyi amaçlayan Teknoloji Kabul Modelinin söz konusu temel unsurları aşağıda açıklanmaktadır:

Dışsal Değişkenler; kullanıcıların, sistemi kullanma derecelerini etkileyen faktörlerdir. Bu faktörler, bireyin demografik veya kişilik özellikleri ile sistemin özelliklerini içermektedir. Sistemin özellikleri, sistemi kullanan bireylerin sistemleri nasıl kullanacaklarını etkilemektedir (Davis, 1985: 21).

Algllanan Fayda, bir bireyin belirli bir sistemi kullanmasının iş performansını geliştireceğine inanma derecesi olarak ifade edilmektedir (Davis, 1985: 26; Davis, 1989: 320). Bir kullanıcının herhangi bir teknolojiyi kullanmasının belli görevleri yaparken ve sorunları çözerken kendisine sağlayacağı performans artışı olarak (Keller, 2005: 302) literatürde yerini almaktadır. Sistemin, "avantajlı olarak kullanılmaya uygunluğunu” ifade eden fayda (yarar) kavramı; teknoloji kullanımı neticesinde bireylerin işlerindeki performans artışlarına ilişkin sahip oldukları olumlu düşünceleri olarak ifade edilmektedir. Dolayısıyla, sistem kullanıcısı tarafından faydası yüksek algılanan bir sistem, olumlu bir kullanımperformans ilişkisinin varlığına inandığı bir sistem olmaktadır (Davis, 1989: 320).

Algılanan Kullanım Kolaylığ zihinsel çaba gerektirmeyeceğine inandığı derece olarak ifade edilmektedir (Davis, 1985: 26). "Sistemin kullanımında zorluk yaşanmamasını ve kullanımının fazla çaba gerektirmemesini" ifade eden kolaylık (rahatlık) kavramı; kişinin belli bir teknolojiyi kullanmayı kolay bulması ve ilgili teknolojinin kullanımının kolayca öğrenilmesi olarak tanımlanmaktadır (Davis, 1989: 320).

Kullanıma Yönelik Tutum, bireyin hedef davranışa yönelik değerlendirme etkisinin derecesini ifade etmektedir (Davis, 1985: 16). Kullanıma yönelik tutum, iki ana inanç olan algılanan fayda ve algılanan kullanım kolaylığının fonksiyonudur. Bir sistemin kullanımına ilişkin bireyin olumlu ya da olumsuz biçimde tepkide bulunma eğilimi olarak ifade edilen tutum (Özer, Özcan ve Aktaş, 2010: 3282) üzerinde algılanan fayda ve algılanan kullanım kolaylığının nedensel bir etkisi vardır (Davis, 1985: 24). 
Davranışsal Kullanım Niyeti, bireyin belirli bir davranışı gerçekleştireceği öznel bir olasılık olarak tanımlanmıştır (Davis, 1985: 16). Dolayısıyla bir kişinin belirli bir davranışı göstermeye yönelik olan şiddetinin ölçüsü olan niyet, bireyin bir davranışı sergilemeye hazır bulunması olarak da açıklanmaktadır. Teknoloji Kabul Modeli, bir bireyin bilişim teknolojilerini kullanmayı kabul etmesinde veya reddetmesinde birincil faktörün, bireyin niyeti olduğunu ileri sürmektedir (Çivici ve Kale, 2007: 121). Tutumdan sonra ve gerçekleşen davranıştan önce gelen niyetin, bireyin davranışının asıl belirleyicisi olduğu, Davis, Bagozzi ve Warshaw'ın (1989) modeli ile ortaya konmuştur.

Gerçekleşen Kullanım, tutumun ve niyetin davranış üzerindeki etkisini gösteren bir değişken olarak TKM'nin davranışsal cevabı olmaktadır (Davis, 1985: 24). Sisteme ilişkin olumlu bir tutuma ve niyete sahip olan bireyden, ilgili sistemi benimseyip fiilen kullanma davranışı göstereceği beklenmektedir.

Teknoloji Kabul Modeli temel olarak, kişilerin teknoloji tercihlerini belirlemek, değişime nasıl tepki verebileceklerini ortaya koyabilmek, insanların bilgi teknolojilerini kullanmaya direnç göstermelerinin nedenlerini açıklamak ve değişime verecekleri cevapları öngörebilmek amaciyla geliştirilmiştir (Uğur ve Turan, 2016: 103). Model; iki özel inanç olan algılanan fayda ve algılanan kullanım kolaylığının, sistemin kabul davranışlarıyla birincil düzeyde ilişkili olduğunu önermektedir (Davis, Bagozzi ve Warshaw, 1989: 985; Agarwal ve Prasad, 1999: 381). Bu iki ana belirleyiciye ek olarak; TKM, dışsal faktörlerin de kullanıcıların sistemi benimsemeleri üzerinde önemli etkileri olacağını öne sürmektedir (Park vd., 2009: 197). Modele göre algılanan kullanım kolaylığı ve algılanan fayda, bir bilgi teknolojisine karşı bireylerin geliştireceği davranışları etkilemektedir. Bu davranış ise bireyin teknolojik bir sistemi kullanma isteğine yön vererek, onu kabul etmesini sağlamaktadır (Adams, Nelson ve Todd, 1992: 229; Davis, Bagozzi ve Warshaw, 1989: 985986). Bu kapsamda algılanan kullanım kolaylığının, algılanan fayda üzerinde anlamlı ve pozitif bir etkisi olduğu kanıtlanmıştır (Kwok ve Yang, 2017: 10; Venkatesh ve Davis, 2000: 197; Jeong, 2011: 54; Yoon, 2016: 692; Lee, 2009: 137). Algılanan faydanın, davranışsal niyet üzerinde anlamlı etkisi olduğunu gösteren ampirik çalışmalar da mevcuttur (Wu ve Wang, 2005: 725; Agarwal ve Prasad, 1999: 377-378; Moon ve Kim, 2001: 226). Algilanan faydanın ve algılanan kullanım kolaylığının tutum üzerinde anlamlı ve pozitif bir etkiye sahip olduğuna ilişkin çalışmaların (Cheng, Sheen ve Lou, 2006: 861; Agarwal ve Prasad, 1999: 377-378; Kim ve Woo, 2016: 271; Yoon, 2016: 692) fazlalığ1; sistemin kullanımının kolay olmasının ve iş performansını iyileştirmeye yardımcı olmasının, bireyin sisteme ilişkin olumlu değerlendirmeler oluşturduğunu göstermektedir. Sistem kullanımına ilişkin davranışın gerçekleştirilmesi için kullanıcının istemlerinin ve çabalarının göstergesi olan niyetin (Özer, Özcan ve Aktaş, 2010: 3282) oluşumunda, tutumun yadsınamaz bir etkisi olduğu yapılan çalışmalarla da kanıtlanmıştır (Moon ve Kim, 2001: 226; Hung ve Chang, 2005: 367; Al-Somali, Gholami ve Clegg, 2009: 139; Munoz-Leiva, Climent-Climent ve Liebana-Cabanillas, 2017: 32; Kim ve Woo, 2016: 271; Wu ve Liao, 2011: 389; Lee, 2009: 137). Bireylerin, sistem kullanımlarına yönelik davranışlarının oluşmasında da niyetin, davranışı şekillendirici etkisi görülmektedir. Genel olarak bireylerin niyetleri doğrultusunda hareket etmeleri nedeniyle de kullanıcıların, sistemi kullanmaya devam etme doğrultusundaki çabalarının tutarlılık göstererek davranışa dönüştüğü görülmektedir (Venkatesh ve Davis, 2000: 195; Wu ve Wang, 2005: 725; Turan ve Haşit, 2014: 116). 


\subsection{Sanal Kart}

Sanal kart; basılı olmayan ve fiziki bir varlığı bulunmayan, bireylerin asıl kredi kartlarına veya banka hesaplarına bağlı olarak oluşturabilecekleri ve limitlerini kendilerinin belirleyebilecekleri bir karttır. İnternet üzerinden güvenli bir şekilde alışveriş yapma imkânı sunan sanal kartlardan y1llık üyelik ücreti, sanal kart oluşturma ve kullanma ücreti alınmamaktadır (Bankacılık Düzenleme ve Denetleme Kurumu (BDDK), 2018). Kartın fiziksel olarak işlem anında bulunmadığı işlemler için hem kartı çıkaran kuruluşlar olan bankaların, müşterilerine sanal kart hizmeti sunmaları hem de üye işyerlerinin sanal kart ile ödemeye destek vermesi gerekmektedir (BDDK Tebliğ Taslağı, 2016).

İnternetten güvenli bir şekilde alışveriş yapmak isteyen tüketicilerin, kredi kartı bilgilerini (kart numaras1, son kullanma tarihi, güvenlik kodu gibi) online mecralarda paylaşmaktan çekinmeleri nedeniyle popülaritesi artmış bir uygulama olan sanal kart; fiziksel varlığı olmayan sanal bir üründür. Fiziksel bir kart olmadığı için de sanal kartın online alışverişler dışında kullanılması mümkün değildir. Bankalar tarafından müşterilerine tamamen ücretsiz olarak sunulan sanal kartın kullanılabilmesi için müşterilerin internet bankacılığını kullanarak asıl kredi kartlarından veya banka hesaplarından sanal kartlarına limit aktarımında bulunmaları gerekmektedir. Limiti, müşterilerin yüklediği kadar olan sanal kartta; online alışveriş sonrası kalan para hesaba geri aktarılarak sanal kartın limiti sıfirlanabilmektedir. Kullanılan sanal kartların kart numarasının, son kullanma tarihinin ve güvenlik kodunun, tüketicinin asıl kredi kartından farklı olması, tüketicilerin internet kanalını kullanarak alışverişlerine ilişkin risksiz bir şekilde ödeme yapabilmesini sağlamaktadır.

\section{Araştırma Yöntemi}

\subsection{Araştırmanın Amacı ve Örnekleme Süreci}

Çalışmanın temel amacı, internet üzerinden online alışveriş yapan müşterilerin, ödeme işlemlerinde sanal kart kullanımlarının kabulünü Teknoloji Kabul Modeline (TKM) dayanarak incelemektir. Bu kapsamda araştırmada; algılanan fayda ve algılanan kullanım kolaylığının, kullanıma yönelik tutum, davranışsal niyet (kullanıma devam etme niyeti) ve gerçekleşen davranış (sanal kart kullanımı) üzerindeki etkilerinin tespit edilmesi amaçlanmaktadır. Söz konusu amaca ulaşmak için oluşturulan araştırma modeli kapsamında veri toplama tekniği olarak çevrimiçi anket yönteminden (Malhotra, 2010: 219) yararlanılmıştır.

Anket çalışmasıyla toplanan verilerin, kuramsal bilgiye bağlı olarak geliştirilmiş olan model ile desteklenip desteklenmediğinin ortaya konulduğu çalışmada; araştırmaya konu olan örneklem, online alışverişlere ilişkin ödemelerini sanal kart kullanarak gerçekleştiren bireyler olarak belirlenmiştir. İnternet üzerinden alışveriş ve ödeme yapmış olan kişilerin elektronik mecralara yatkın olacağı düşüncesinden hareketle, verinin toplandığ anket formu çevrimiçi anket olarak tasarlanmış ve cevaplayıcıların çevrimiçi anket formuna, bir internet bağlantı linki ile ulaşması sağlanmıştır. Anket linki, bir yandan araştırmacının sosyal medya uygulamaları olan Linkedin ve Instagram üzerinden paylaşılmış, diğer yandan da araştırmacının mail listesinde bulunan ve internetten güvenli alışveriş yapabilmek için sanal kart kullandığı düşünülen kişilere ilgili link gönderilmiş ve mail gönderilen kişilerin de 
kendi mail listelerindeki ilgili kişilere linki göndermeleri istenmiştir. Araştırmanın sorunsalına uygun geldiği düşünülen belirli özellikleri taşıyan deneklerden verinin toplanmasını temel alan yargısal (amaçlı) örneklemenin ve öncesinde araştırmanın kıstaslarına uygun bir veya birkaç deneğin tespiti ile sonrasında da bu deneklerden elde edilen bilgiler ve/veya tavsiyelerle aynı özellikleri taşıyan başka deneklere ulaşılarak kartopu örneklemesinin (Gürbüz ve Şahin, 2016: 134-135) araştırmada kullanılması benimsenmiştir. Araştırmanın örneklem büyüklüğünün belirlenmesi kapsamında $n=\pi(1-\pi) /(\mathrm{e} / \mathrm{Z})^{2}$ formülü kullanılarak \% 5 hata payı ve \% 95 güven aralığında ulaşılması gerekli alt sınırın 384 olduğu tespit edilmiştir (Kurtuluş, 2010: 67).

Anket çalışması 16.11.2017 - 16.01.2018 tarihleri arasında yapılmıştır. İlk olarak ön test kapsamında 50 cevaplayıcıya anket formu uygulanmış, veri kalitesinde iyileşme sağlayacak herhangi bir düzeltmeye ve sadeleştirmeye gerek duyulmaması nedeniyle aynı anket formuyla çalışmanın bütün verileri toplanmıştır. Okumadan yapılmış olması ihtimali nedeniyle cevaplama süresi 3 dakikanın altında kalan cevaplamalar değerlendirme dışında bırakılarak ulaşılan ve analize elverişli olan 490 nihai anket analize tabi tutulmuştur.

\subsection{Hipotezler ve Araştırma Modeli}

Araştırma modelinin oluşturulmasında Davis, Bagozzi ve Warshaw'ın (1989) Teknoloji Kabul Modelinden hareket edilmiştir. Literatürde yapılan çalışmalar, tüketicinin sisteme ilişkin inançları olan algıladığı faydanın ve algılanan kullanım kolaylığının tutumu etkilediğini, tutumun niyeti şekillendirdiğini ve niyetin de gerçekleşen davranışı belirleyen önemli bir faktör olduğunu göstermektedir (Moon ve Kim, 2001: 225; Cheng, Sheen ve Lou, 2006: 861; Lemay vd., 2018: 34). Söz konusu bulgulardan hareketle, araştırma kapsamında tüketicilerin sanal kart kullanımına ilişkin kabullerinin açıklanması için aşağıdaki hipotezler oluşturulmuştur:

H1: Online alışverişlerde sanal karta yönelik algılanan kullanım kolayliğının algılanan fayda üzerinde pozitif etkisi vardır.

H2: Online alışverişlerde sanal karta yönelik algılanan faydanın tutum üzerinde pozitif etkisi vardir.

H3: Online alışverişlerde sanal karta yönelik algılanan kullanım kolaylı̆̆ının tutum üzerinde pozitif etkisi vardir.

H4: Online alışverişlerde sanal karta yönelik algılanan faydanın sanal kart kullanım niyeti üzerinde pozitif etkisi vardır.

H5: Online alışverişlerde sanal kart kullanımına yönelik tutumun niyet üzerinde pozitif etkisi vardir.

H6: Online alışverişlerde sanal karta yönelik davranışsal niyetin, sanal kart kullanımı üzerinde pozitif etkisi vardır.

Oluşturulan hipotezler kapsamında, araştırma modelinin şematik gösterimi Şekil 2'de sunulmaktadır: 
Şekil 2. Araştırma Modeli

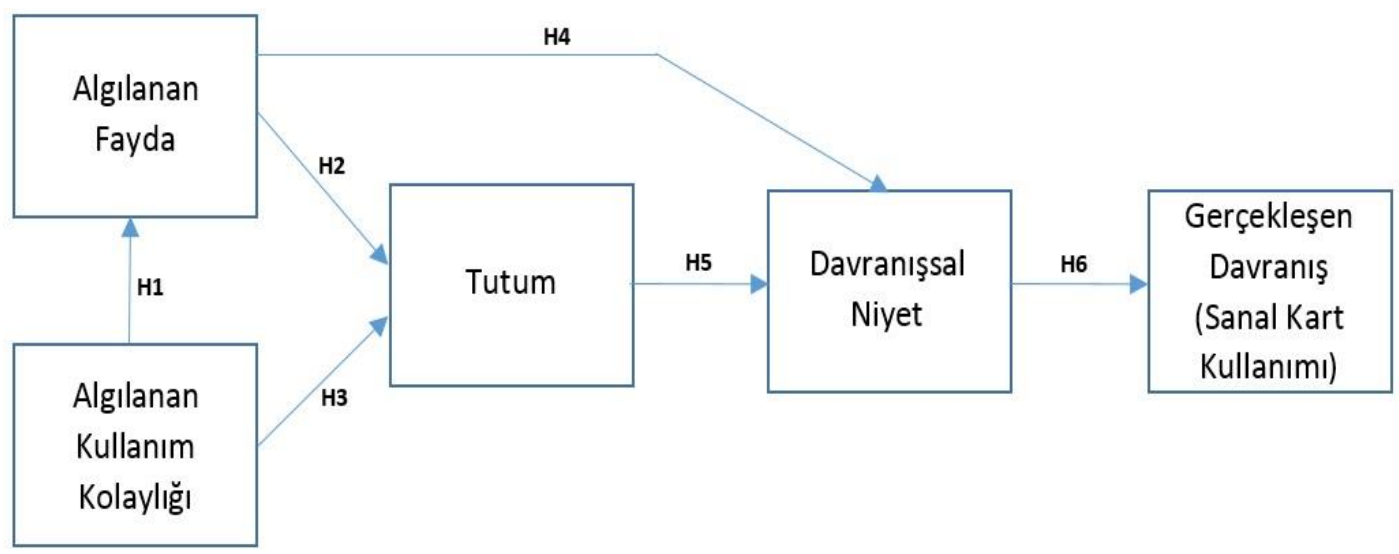

\subsection{Anket Formunun Oluşturulması ve Kullanılan Ölçekler}

Üç bölüm olarak tasarlanan anket formunun ilk bölümünde, cevaplayıcıların online alışverişlerinde güvenli şekilde ödeme yapabilmek için geliştirilmiş olan sanal kart uygulamasını kullanıp kullanmadıkları sorulmuş ve kullanmayanlar için anket otomatik olarak sonlandırılmıştır. İkinci bölümde, çalışma kapsamında test edilen değişkenler olan algılanan fayda, algılanan kullanım kolaylığı, tutum, davranışsal niyet ve gerçekleşen davranışı ölçmeye yönelik geçerliliği ve güvenilirliği test edilmiş ölçek ifadelerine yer verilmiştir. Araştırmada kullanılan ölçeklerin hepsi daha önceden yapılmış çalışmaların geçerliliği ve güvenilirliği test edilmiş olan mevcut ölçekleri olup, bu ölçekler değişkenleri test etmek amaciyla ankette sorulan sorulardan oluşmuş ve alan yazının derinlemesine incelenmesi sonucunda alınıp çalışmaya adapte edilmiştir. Ölçeklerin geçerliliği tercüme ve yeniden tercüme süreci izlenerek test edilmiştir. Araştırmada kullanılan tüm ölçekler tek boyuttan oluşmaktadır. Algılanan fayda ve algılanan kullanım kolaylığı değişkenlerini ölçmek için Venkatesh ve Davis (2000: 201) tarafından geliştirilen ve dörder sorudan oluşan ölçekler kullanılmıştır. Tutum değişkeni için kullanılan ölçek Alharbi ve Drew'in (2014: 149) çalışmasından alınmıştır ve değişken üç ifade ile ölçülmektedir. Davranışsal niyet değişkeni için kullanılan ve üç sorudan oluşan ölçek de Cronin, Brady ve Hult (2000: 213)'ın çalışmasından uyarlanmıştır. Gerçekleşen davranış değişkenini ölçmek üzere de Özer, Özcan ve Aktaş (2010: 3288) tarafından geliştirilen ve iki ifadeden oluşan ölçek kullanılmıştır. İfadeler 5'li Likert tipi ölçekle [(1) Hiç Katılmıorum...(5) Tam Katılıyorum] cevaplayıcılara sorulmuştur. Anketin son bölümü olan üçüncü bölümde de cevaplayıcıların sosyo-demografik özelliklerini belirlemeye yönelik eğitim düzeyi, aylık kişisel gelir, medeni durum, çalışma durumu, cinsiyet ve yaş aralığı gibi ifadelere yer verilmiştir.

\subsection{Verilerin Analiz Yöntemi}

Çalışmanın istatistiksel analiz kısmında modelin test edilmesi için üç aşamalı yaklaşım benimsenmiştir. Öncelikli olarak ölçeklerin yapısal geçerliliğini ve tek boyutluluğunu tespit etmek amacıyla Açıklayıcı Faktör Analizi (AFA) yapılırken; ölçek maddelerinin kendi aralarındaki içsel tutarlılıklarını tespit etmek için de Cronbach Alpha güvenilirlik katsayıları hesaplanmıştır. Ardından, ölçüm modelinin test edilmesi bağlamında 
kullanılan ölçeklerin araştırma kapsamında toplanan verilerle doğrulandığını gösterebilmek için Doğrulayıcı Faktör Analizi (DFA) yapılmıştır. Doğrulayıcı Faktör Analizi aşamasında test edilen ölçüm modelinin güvenilirlik ve geçerlilik testleri yapılmıştır. Ölçme modelinin doğrulanmasından sonra da, araştırma kapsamında sunulan hipotezler test edilmiş; bu bağlamda yapısal modelde yer alan doğrudan ilişkilerin test edilmesinde Yol Analizi uygulanmıştır. Çalışmada verilerin analizi SPSS 23 ve AMOS 24 paket programları ile yapılmıştır.

\section{Analiz ve Bulgular}

\section{1. Örneklemin Demografik Özellikleri ve Tanımlayıcı İstatistikler}

Araştırma neticesinde elde edilen bulguların değerlendirilmesi amaciyla öncelikle anketi cevaplayan 490 kişiyle ilgili demografik veriler Tablo 1'de sunulmaktadır. İlgili tablo incelendiğinde, ankete katılan cevaplayıcıların medeni durum açısından eşit dağılımda olduğu görülmekle beraber, en son aldıkları derece açısından eğitim düzeylerinin yüksek olduğu (\% 62'si lisans derecesine sahipken \% 22,9'u da lisansüstü dereceye sahiptir) ve kadınların oranının erkeklere göre daha fazla olduğu söylenebilir (\% 56,3 kadın, \% 43,7 erkek).

Araştırmaya konu olan örneklemin yaş aralığı çeşitlilik göstermekle birlikte, bireylerin beşte dördü (\% 84,9) 18-37 yaş aralığındadır. Bu oranın \% 24,7'sini 23-27 yaş aralığındaki, \% 23,7'sini 33-37 yaş aralığındaki, \% 21'ini 28-32 yaş aralığındaki ve \% 15,5'ini de 18-22 yaş aralığındaki bireyler oluşturmaktadır. Nispeten genç bir örneklem çoğunluğu oluştursa da 38-42 yaş aralığındakilerin oranının da azımsanamayacak düzeyde $(\%$ 8,4) olduğu görülmektedir.

Öte yandan anketi cevaplayan bireylerin aylık kişisel gelirleri çeşitlilik göstermekle birlikte çoğunluğunun alt orta ve üst orta gelir grubu aralığında olduğu söylenebilir. Bununla beraber, çalışma durumu açısından cevaplayıcıların kamu ve özel sektör çalışanı olarak eşit dağılıma sahip olduğu ve onları sırasıyla öğrencilerin ve serbest meslek erbabının izlediği bulgusuna ulaşılmıştır.

Araştırma modeli, Yapısal Eşitlik Modellemesi (YEM) kullanılarak test edilmiş ve YEM çalışmalarında temel olarak kullanılan kestirim yöntemi olarak da Maksimum Olabilirlik Tahmin Yöntemi (Maximum Likelihood Estimation) kullanılmıştır (Şimşek, 2007: 55). Bu yöntemin kullanılabilmesi için verilerin sürekli değişken olması ve normallik koşulunu karşılaması gerekmektedir (Gürbüz \& Şahin, 2016: 333).

Yapısal Eşitlik Modellemesi analizlerinde, normal dağılmış bir veri için genel olarak 100 sayısının asgari, 200 sayısının da kabul edilebilir sınırlar içerisinde olduğu ifade edilmekle birlikte; gözlenen değişken sayısının on katı civarında bir örneklem sayısı, verinin normal dağıldığı ve değişkenler arasındaki ilişkilerin göreceli olarak yüksek olduğu modellerde yeterli olarak kabul edilmektedir (Şimşek, 2007: 55). Bu noktadan hareketle, araştırma kapsamında toplanan ve analize elverişli olan 490 kişiye ait verinin analiz için yeterli düzeyde olduğu söylenebilir. 
Tablo 1. Anketi Cevaplayan Bireylerin Demografik Değişkenlere İlişkin Dağılımları

\begin{tabular}{|c|c|c|c|c|c|}
\hline & n (490) & $\%$ & & n (490) & $\%$ \\
\hline Ĕ̆itim Düzeyi & & & Cinsiyet & & \\
\hline Lise ve alt 1 & 59 & 12,0 & Kadın & 276 & 56,3 \\
\hline Ön lisans & 15 & 3,1 & Erkek & 214 & 43,7 \\
\hline Lisans & 304 & 62,0 & Medeni Durum & & \\
\hline Lisansüstü & 112 & 22,9 & Evli & 244 & 49,8 \\
\hline Gelir Düzeyi & & & Bekâr & 246 & 50,2 \\
\hline $1500 \mathrm{TL}$ ve alt 1 & 81 & 16,5 & Yaş & & \\
\hline $1501 \mathrm{TL}-3000 \mathrm{TL}$ aras 1 & 35 & 7,2 & $18-22$ & 76 & 15,5 \\
\hline $3001 \mathrm{TL}-4500 \mathrm{TL}$ aras1 & 155 & 31,6 & $23-27$ & 121 & 24,7 \\
\hline $4501 \mathrm{TL}-6000 \mathrm{TL}$ aras1 & 118 & 24,1 & $28-32$ & 103 & 21,0 \\
\hline 6501 TL ve üstü & 101 & 20,6 & $33-37$ & 116 & 23,7 \\
\hline Çalışma Durumu & & & $38-42$ & 41 & 8,4 \\
\hline Kamu Çalışanı & 153 & 31,3 & $43-47$ & 16 & 3,3 \\
\hline Özel Sektör Çalışanı & 154 & 31,4 & $48-52$ & 10 & 2,0 \\
\hline Serbest Meslek Erbabı & 70 & 14,3 & 53 ve üstü & 7 & 1,4 \\
\hline Emekli & 8 & 1,6 & & & \\
\hline Ev Hanımı & 8 & 1,6 & & & \\
\hline Öğrenci & 89 & 18,2 & & & \\
\hline İşsiz & 8 & 1,6 & & & \\
\hline
\end{tabular}

Öte yandan araştırma kapsamında yer alan örtük değişkenlere ait gözlenen değişkenlerin normallik dağılımlarını ortaya çıkarmak ve dağılım yapısının anlaşılmasını sağlamak için çarpıklık ve basıklık değerleri de kontrol edilmiştir (Gürbüz ve Şahin, 2016: 216). Bu kapsamda araştırmada test edilen modelin gözlenen değişkenlerinin ortalaması, standart sapması, çarpıklık ve basıklık değerleri Tablo 2'de sunulmaktadır. Çalışmada test edilen ölçeklere ilişkin veri setinin çarpıklık ve basıklık değerlerinin istenilen sınırlar arasında olduğu görülmüştür. Araştırma modelindeki değişkenlerin çarpıklık değerinin 2'den basıklık değerinin de 7'den düşük olması (Hong vd., 2003: 642, West vd., 1995 aktaran Dölarslan ve Özer, 2014: 44) nedeniyle verinin normal dağılım özelliğini gösterdiği söylenebilir. 
Tablo 2. Araştırma Modelindeki Ölçeklere İlişkin Tanımlayıcı İstatistikler $(\mathrm{n}=490)$

\begin{tabular}{|c|c|c|c|c|c|}
\hline \multicolumn{2}{|c|}{ Ölçekler } & Ort. & S.S. & Çarpıklık & Basıklık \\
\hline \multicolumn{2}{|c|}{ Algılanan Fayda (AF) } & 4,097 & 0,712 & $-0,812$ & 0,627 \\
\hline AF1 & $\begin{array}{l}\text { Güvenilir bir bankacılık ürünü olan sanal kartı kullanmak online } \\
\text { alışveriş performansımı arttırır. }\end{array}$ & 4,09 & 0,837 & $-0,699$ & 0,043 \\
\hline AF2 & $\begin{array}{l}\text { Sanal kart kullanmak online alışverişlerde endişemi azaltarak güvenli ve } \\
\text { hızlı alışveriş yapma deneyimi sağlar. }\end{array}$ & 4,09 & 0,804 & $-0,677$ & 0,447 \\
\hline AF3 & $\begin{array}{l}\text { Sanal kart, online alışverişlerimde yaptığım ödeme işlemlerinin } \\
\text { güvenliğini sağlar. }\end{array}$ & 4,12 & 0,843 & $-0,815$ & 0,365 \\
\hline AF4 & $\begin{array}{l}\text { Online alışverişlerde, ödeme işlemlerinin güvenliğinin arttırılması için } \\
\text { sanal kart kullanmayı faydalı buluyorum. }\end{array}$ & 4,09 & 0,847 & $-0,753$ & 0,154 \\
\hline \multicolumn{2}{|r|}{ Algılanan Kullanım Kolaylığı (AKK) } & 4,269 & 0,611 & $-1,129$ & 1,592 \\
\hline AKK1 & Online alışverişlerimde sanal kart kullanmak oldukça açık ve anlaşılırdır. & 4,25 & 0,747 & $-0,732$ & 0,088 \\
\hline AKK2 & $\begin{array}{l}\text { Online alışverişlerimde sanal kart kullanmak çok fazla zihinsel çaba } \\
\text { gerektirmez. }\end{array}$ & 4,21 & 0,752 & $-0,794$ & 0,648 \\
\hline AKK3 & Online alışverişlerimde sanal kart kullanmak kolaydır. & 4,40 & 0,736 & $-1,087$ & 0,750 \\
\hline AKK4 & $\begin{array}{l}\text { Online alışverişlerimin güvenliğini, sanal kart kullanarak kolayca } \\
\text { sağlayabilirim. }\end{array}$ & 4,23 & 0,737 & $-0,693$ & 0,137 \\
\hline \multicolumn{2}{|c|}{ Tutum (T) } & 3,884 & $\mathbf{0 , 7 2 9}$ & $-\mathbf{0 , 6 5 0}$ & 0,364 \\
\hline $\mathrm{T} 1$ & $\begin{array}{l}\text { Online alışverişlerimde sanal kart kullanmanın doğru bir düşünce } \\
\text { olduğuna inanıyorum. }\end{array}$ & 3,87 & 0,795 & $-0,453$ & 0,163 \\
\hline $\mathrm{T} 2$ & $\begin{array}{l}\text { Ödeme güvenliği sağladığı için online alışverişlerde sanal kart kullanma } \\
\text { fikrini seviyorum. }\end{array}$ & 3,92 & 0,819 & $-0,458$ & $-0,129$ \\
\hline T3 & $\begin{array}{l}\text { Online alışverişlerimde sanal kart kullanmanın gerekli bir seçim } \\
\text { olduğunu düşünüyorum. }\end{array}$ & 3,86 & 0,868 & $-0,575$ & 0,238 \\
\hline \multicolumn{2}{|c|}{ Davranışsal Niyet (DN) } & 3,845 & 0,806 & $-0,746$ & $\mathbf{0 , 3 7 7}$ \\
\hline DN1 & $\begin{array}{l}\text { Online alışverişlerimde sanal kartı, büyük ihtimalle kullanmaya devam } \\
\text { edeceğim. }\end{array}$ & 3,91 & 0,854 & $-0,588$ & 0,143 \\
\hline DN2 & $\begin{array}{l}\text { Online alışverişlerine ilişskin güvenli ödeme yapabilmeleri için sanal kart } \\
\text { kullanmalarını arkadaşlarıma tavsiye edeceğim. }\end{array}$ & 3,78 & 0,952 & $-0,678$ & 0,316 \\
\hline DN3 & $\begin{array}{l}\text { Online alışverişlerimdeki ödeme işlemlerimin güvenliğine ilişkin bir } \\
\text { seçim yapmak zorunda kalırsam yine sanal kart kullanmayı tercih } \\
\text { ederim. }\end{array}$ & 3,84 & 0,953 & $-0,598$ & $-0,017$ \\
\hline \multicolumn{2}{|c|}{ Gerçekleşen Davranış (GD) } & 3,912 & 0,900 & $-0,861$ & 0,457 \\
\hline GD1 & Online alışverişlerimi güvenle yapabilmek için sanal kartı sık kullanırım. & 3,87 & 1,019 & $-0,831$ & 0,302 \\
\hline GD2 & $\begin{array}{l}\text { Online alışverişlerimi güvenle yapabilmek için sanal kartı çok sık } \\
\text { kullanırım. }\end{array}$ & 3,96 & 0,952 & $-0,867$ & 0,556 \\
\hline
\end{tabular}

\subsection{Açıklayıcı Faktör Analizi}

Araştırma kapsamındaki ölçeklere, Temel Bileşenler Analizi ve Varimaks eksen döndürmesi tekniği kullanılarak AFA uygulanmıştır. Her bir değişken için Bartlett Küresellik Testinin anlamlı olması (p-değeri: 0,000) maddeler arasındaki korelasyon ilişkilerinin faktör analizi için uygun olduğuna işaret ederken; Kaiser-Meyer-Olkin (KMO) değerleri (kabul edilebilir en alt sınır 0,50) de örneklemin büyüklügünün faktör analizi için yeterli olduğunu göstermektedir (Durmuş, Yurtkoru ve Çinko, 2013: 80). Araştırmaya konu olan değişkenlerin tümünün \%50'den büyük açıklanan varyans değerlerine ve 1 'den büyük özdeğere sahip olması (Tablo 3) sebebiyle her bir değişkenin tek bir boyutta (Dölarslan ve Özer, 2014: 45) açıklandığı sonucu elde edilmiştir. Öyle ki, tek boyutlu yapıda olan Algılanan Fayda (AF) değişkeninin \% 73,169, Algılanan Kullanım Kolaylığı (AKK) değişkeninin \% 67,689, Tutum (T) değişkeninin \% 77,831, Davranışsal Niyet (DN) değişkeninin \% 76,670 ve Gerçekleşen Davranış (GD) değişkeninin \% 83,331 oranında açıklanan varyans değerine sahip olduğu bulgusuna ulaşılmıştır. Ayrıca ölçeklerde yer alan 
ifadelerin iç tutarlılık güvenilirliğini belirlemek amacıyla da her bir ölçeğin Cronbach Alpha

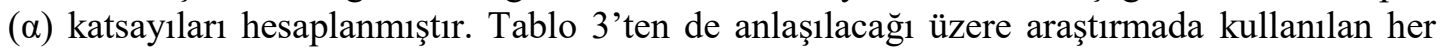
bir ölçeğin 0,80 ve üzerinde olması nedeniyle yüksek derecede güvenilirliğe (Kayış, 2006: 405) sahip olduğu görülmektedir. Dolayısıyla AFA ile açıklanan değişkenlerin, kuramsal yapısının doğrulanması için DFA'ya geçilmiştir.

Tablo 3. Açıklayıcı Faktör Analizi Sonuçları $(\mathrm{n}=490)$

\begin{tabular}{|c|c|c|c|c|c|}
\hline $\begin{array}{c}\text { Örtük } \\
\text { Değişken }\end{array}$ & $\begin{array}{l}\text { Gözlenen } \\
\text { Değişkenler }\end{array}$ & Özdeğer & $\begin{array}{c}\text { Açılklanan } \\
\text { Varyans } \\
(\%)\end{array}$ & $\begin{array}{c}\text { Kümülatif } \\
\text { Varyans } \\
(\%)\end{array}$ & $\begin{array}{c}\text { Cronbach's } \\
\text { Alpha }(\alpha)\end{array}$ \\
\hline \multirow[t]{4}{*}{$\mathrm{AF}$} & AF1 & 2,927 & 73,169 & 73,169 & \multirow{4}{*}{0,877} \\
\hline & $\mathrm{AF} 2$ & 0,431 & 10,769 & 83,938 & \\
\hline & AF3 & 0,369 & 9,224 & 93,162 & \\
\hline & AF4 & 0,274 & 6,838 & 100,000 & \\
\hline \multicolumn{6}{|c|}{$\begin{array}{l}\text { KMO (Örneklem Yeterliliği): } 0,827 \\
\text { Bartlett Küresellik Testi: }\left[x^{2}(6)=1003,756, p<0,001\right]\end{array}$} \\
\hline \multirow[t]{4}{*}{ AKK } & AKK1 & 2,708 & 67,689 & 67,689 & \multirow{4}{*}{0,841} \\
\hline & AKK2 & 0,534 & 13,361 & 81,050 & \\
\hline & AKK3 & 0,416 & 10,410 & 91,459 & \\
\hline & AKK4 & 0,342 & 8,541 & 100,000 & \\
\hline \multicolumn{6}{|c|}{$\begin{array}{l}\text { KMO (Örneklem Yeterliliği): } 0,797 \\
\text { Bartlett Küresellik Testi: }\left[x^{2}(6)=769,532, p<0,001\right]\end{array}$} \\
\hline \multirow[t]{3}{*}{$\mathrm{T}$} & $\mathrm{T} 1$ & 2,335 & 77,831 & 77,831 & \multirow{3}{*}{0,856} \\
\hline & $\mathrm{T} 2$ & 0,402 & 13,405 & 91,236 & \\
\hline & $\mathrm{T} 3$ & 0,263 & 8,764 & 100,000 & \\
\hline \multicolumn{6}{|c|}{$\begin{array}{l}\text { KMO (Örneklem Yeterliliüi): } 0,719 \\
\text { Bartlett Küresellik Testi: }\left[x^{2}(3)=681,464, p<0,001\right]\end{array}$} \\
\hline \multirow[t]{3}{*}{ DN } & DN1 & 2,300 & 76,670 & 76,670 & \multirow{3}{*}{0,847} \\
\hline & DN2 & 0,402 & 13,395 & 90,066 & \\
\hline & DN3 & 0,298 & 9,934 & 100,000 & \\
\hline \multicolumn{6}{|c|}{$\begin{array}{l}\text { KMO (Örneklem Yeterliliği }): 0,722 \\
\text { Bartlett Küresellik Testi: }\left[x^{2}(3)=628,085, p<0,001\right]\end{array}$} \\
\hline \multirow[t]{2}{*}{ GD } & GD1 & 1,667 & 83,331 & 83,331 & \multirow{2}{*}{0,799} \\
\hline & GD2 & 0,333 & 16,669 & 100,000 & \\
\hline
\end{tabular}

\subsection{Doğrulayıcı Faktör Analizi: Ölçüm Modeli}

Çalışmada; daha önceden geliştirilmiş, geçerliliği ve güvenilirliği test edilmiş, önceki araştırmalarda kullanılmış ve kuramsal dayanağı bulunan ölçekler kullanıldığı için söz konusu ölçeklerin çalışmanın veri seti ile doğrulanması amacıyla DFA tercih edilmiştir (Gürbüz ve Şahin, 2016: 309). Tek boyutlulukları AFA ile belirlenen değişkenlerin, DFA ile ölçüm modeli test edilmiştir. Bu kapsamda, tüm ölçüm modelini oluşturan değişkenler DFA ile analize alınmıştır. Araştırma modeli kapsamında 5 örtük değişkeni yordayan 16 gözlenen 
değişkene ait elde edilen DFA sonuçları ile ölçüm modeline ilişkin uyum iyiliği değerleri Tablo 4'te sunulmaktadır.

Tablo 4. Doğrulayıcı Faktör Analizi Sonuçları $(n=490)$

\begin{tabular}{|c|c|c|c|c|c|}
\hline $\begin{array}{c}\text { Örtük } \\
\text { Değişkenler }\end{array}$ & $\begin{array}{c}\text { Gözlenen } \\
\text { Değişkenler }\end{array}$ & $\begin{array}{l}\text { Standardize Edilmiş } \\
\text { Parametre Değerleri } \\
(\beta)\end{array}$ & $\begin{array}{c}\text { Standart } \\
\text { Hata }\end{array}$ & $\mathbf{t}$ & $\mathbf{p}$ \\
\hline \multirow[t]{4}{*}{$\mathrm{AF}$} & AF1 & 0,764 & & & \\
\hline & $\mathrm{AF} 2$ & 0,775 & 0,046 & 21,117 & $0,000 * *$ \\
\hline & AF3 & 0,826 & 0,060 & 18,012 & $0,000 * *$ \\
\hline & $\mathrm{AF} 4$ & 0,777 & 0,061 & 16,959 & $0,000 * *$ \\
\hline \multirow[t]{4}{*}{$\mathrm{AKK}$} & AKK1 & 0,765 & & & \\
\hline & AKK2 & 0,772 & 0,059 & 17,168 & $0,000 * *$ \\
\hline & AKK3 & 0,776 & 0,060 & 16,536 & $0,000 * *$ \\
\hline & AKK4 & 0,753 & 0,061 & 15,991 & $0,000 * *$ \\
\hline \multirow[t]{3}{*}{$\mathrm{T}$} & $\mathrm{T} 1$ & 0,826 & & & \\
\hline & $\mathrm{T} 2$ & 0,860 & 0,050 & 21,495 & $0,000 * *$ \\
\hline & $\mathrm{T} 3$ & 0,773 & 0,054 & 18,833 & $0,000 * *$ \\
\hline \multirow[t]{3}{*}{$\mathrm{DN}$} & DN1 & 0,778 & & & \\
\hline & DN2 & 0,847 & 0,064 & 19,019 & $0,000 * *$ \\
\hline & DN3 & 0,798 & 0,064 & 17,951 & $0,000 * *$ \\
\hline \multirow[t]{2}{*}{ GD } & GD1 & 0,811 & & & \\
\hline & GD2 & 0,822 & 0,055 & 17,112 & $0,000 * *$ \\
\hline
\end{tabular}

DFA sonuçları neticesinde, ölçüm modeline ait uyum iyiliği değerlerinin $(\mathrm{p}<0,001$, $\mathrm{x}^{2}=180,543$, Serbestlik Derecesi $(\mathrm{sd})=92, \mathrm{x}^{2} / \mathrm{sd}=1,962, \mathrm{RMSEA}=0,044, \mathrm{CFI}=0,981$, $\mathrm{GFI}=0,957, \mathrm{IFI}=0,981, \mathrm{TLI}=0,975)$ genel olarak literatürdeki kabul edilebilir değerlerin üstünde olduğu (Schermelleh-Engel, Moosbrugger ve Müller, 2003: 52; Gürbüz ve Şahin, 2016: 337, Çokluk, Şekercioğlu ve Büyüköztürk, 2014: 271-272), dolayısıyla toplanan verilerin araştırmada kullanılan ölçeklerin kuramsal yapısına uyum sağladığı tespit edilmiştir.

Ölçüm modeli, örtük değişkenlere ilişkin standardize edilmiş parametre değerleri açısından incelendiğinde de, standardize edilmiş parametre değerlerinin zorunlu koşul olan 0,50 'den ve ideal değer olan 0,70 'den yüksek olduğu ve istatistiksel açıdan anlamlı olduğu (Malhotra, 2010: 734; Hair vd., 2006: 777) ( $\mathrm{p}<0$,001) görülmektedir. Bu aşamadan sonra, ölçüm modelinin geçerlilik ve güvenilirlik analizleri yapılmıştır.

Ölçüm modelinin güvenilirliğinin ortaya konulması açısından yapı güvenilirliği (Composite Reliability-CR) değerlerinin, Malhotra (2010: 734)'nın da önerdiği gibi kabul edilebilir alt sınır olan 0,70 'den yüksek olması önemli bir gösterge olmaktadır. Araştırma modeli açısından değerlendirildiğinde; yap1 güvenilirliği değerlerinin önerilen 0,70'lik düzeyin üzerinde olması, ölçüm modelinin güvenilirliği sağlaması açısından kabul edilebilir olduğunu göstermektedir. 
Ölçüm modelinin geçerliliği için ise, değişkenlere ilişkin ifadelerin birbirleriyle ve oluşturdukları faktör ile yüksek düzeyde ilişkili olması (yakınsak geçerlilik) ve değişkenlere ilişkin ifadelerin ait olduğu faktörün; diğer faktörlerle, kendi bulundukları faktörden daha az düzeyde ilişkili olması (1raksak geçerlilik) gerekmektedir (Yaşlığlu, 2017: 82). Yakınsak geçerlilik için ölçeklere ilişkin tüm yapı güvenilirliği değerlerinin ortalama açıklanan varyans (Average Variance Extracted-AVE) değerlerinden büyük olmas1 ve AVE değerlerinin de 0,50'den büyük olması beklenmektedir (Bagozzi ve Yi, 1988: 82; Yaşlığlu, 2017: 82). Bu doğrultuda DFA kapsamında analiz edilen ölçüm modelinin, her bir yapıyı (örtük değişkeni) oluşturan gözlenen değişkenlerin, ortalama açıklanan varyans değerlerinin önerilen sınır değer olan 0,50'den yüksek olması hasebiyle yakınsak geçerliliğe sahip olduğu ifade edilebilir. Iraksak geçerliliğin test edilmesinde ise örtük değişkenler arasındaki korelasyonların karelerinin (paylaşılan varyans değerlerinin) her bir yapı için ortalama açıklanan varyans değerinden düşük olması koşulunun sağlanması aranmaktadır (Fornell ve Larcker, 1981 aktaran Dölarslan ve Özer, 2014: 48; Arıkan ve Telci, 2014: 97). Araştırma kapsamında elde edilen değerlere göre ölçüm modelini oluşturan örtük değişkenler arasındaki ıraksak geçerliliğin sağlandığı ifade edilebilir. Dolayısıyla ölçüm modelinin güvenilirliğine, yakınsak ve rraksak geçerliliğine ilişkin elde edilen değerler Tablo 5 'te sunulmaktadır.

Tablo 5. Ölçüm Modelinin Güvenilirliği, Yakınsak ve Iraksak Geçerliliği (n= 490)

\begin{tabular}{|c|c|c|c|c|c|c|}
\hline & Yapı Güvenilirliği & $\mathbf{A F}$ & AKK & $\mathbf{T}$ & DN & GD \\
\hline $\mathbf{A F}$ & 0,87 & 0,62 & & & & \\
\hline AKK & 0,85 & $0,56\left(0,75^{2}\right)$ & $\mathbf{0 , 5 9}$ & & & \\
\hline $\mathbf{T}$ & 0,86 & $0,54\left(0,74^{2}\right)$ & $0,40\left(0,62^{2}\right)$ & 0,67 & & \\
\hline DN & 0,85 & $0,41\left(0,64^{2}\right)$ & $0,38\left(0,61^{2}\right)$ & $0,59\left(0,77^{2}\right)$ & 0,65 & \\
\hline GD & 0,80 & $0,41\left(0,64^{2}\right)$ & $0,44\left(0,66^{2}\right)$ & $0,50\left(0,71^{2}\right)$ & $0,54\left(0,73^{2}\right)$ & 0,67 \\
\hline
\end{tabular}

\subsection{Yapısal Modelin Test Edilmesi}

Ölçüm modelinin doğrulanmasından sonra araştırma modelinin içerdiği doğrudan ilişkilere ilişkin örtük yapısal model test edilmiştir ve elde edilen veriler Tablo 6' da sunulmaktadır. Yol analizi sonucunda elde edilen uyum indekslerinin $\left(\mathrm{p}<0,001, \mathrm{x}^{2}=\right.$ 218,082, Serbestlik Derecesi $(\mathrm{sd})=94, \mathrm{x}^{2} / \mathrm{sd}=2,320$, RMSEA $=0,052, \mathrm{CFI}=0,973$, GFI $=$ $0,950, \mathrm{IFI}=0,973, \mathrm{TLI}=0,966$ ) eşik değerlerin üzerinde olmas1, modelin veri ile iyi seviyede uyumlu olduğuna işaret etmektedir (Schermelleh-Engel, Moosbrugger ve Müller, 2003: 52; Gürbüz ve Şahin, 2016: 337, Çokluk, Şekercioğlu ve Büyüköztürk, 2014: 271-272). 
Tablo 6. Yapısal Modelin Hipotez Testi Sonuçları $(\mathrm{n}=490)$

\begin{tabular}{|c|c|c|c|c|c|c|}
\hline Hipotezler & $\begin{array}{c}\text { Doğrudan } \\
\text { Etkiler }\end{array}$ & $\begin{array}{c}\text { Standardize } \\
\text { Edilmiş } \\
\text { Parametre } \\
\text { Değerleri }(\beta) \\
\end{array}$ & $\begin{array}{l}\text { Standart } \\
\text { Hata }\end{array}$ & $\mathbf{t}$ & $\mathbf{p}$ & Sonuçlar \\
\hline $\mathrm{H} 1$ & $\mathrm{AKK} \rightarrow \mathrm{AF}$ & 0,767 & 0,072 & 12,584 & $0,000^{* *}$ & Desteklendi \\
\hline $\mathrm{H} 2$ & $\mathrm{AF} \rightarrow \mathrm{T}$ & 0,548 & 0,077 & 6,800 & $0,000 * *$ & Desteklendi \\
\hline $\mathrm{H} 3$ & $\mathrm{AKK} \rightarrow \mathrm{T}$ & 0,268 & 0,086 & 3,515 & $0,000 * *$ & Desteklendi \\
\hline $\mathrm{H} 4$ & $\mathrm{AF} \rightarrow \mathrm{DN}$ & 0,119 & 0,075 & 1,649 & 0,099 & Desteklenmedi \\
\hline H5 & $\mathrm{T} \rightarrow \mathrm{DN}$ & 0,752 & 0,092 & 8,777 & $0,000 * *$ & Desteklendi \\
\hline H6 & $\mathrm{DN} \rightarrow \mathrm{GD}$ & 0,782 & 0,070 & 13,793 & $0,000 * *$ & Desteklendi \\
\hline \multirow{4}{*}{\multicolumn{2}{|c|}{ Açıklanma Değeri $\left(\mathbf{R}^{2}\right)$}} & $\mathrm{R}^{2} \mathrm{AF}=0,59$ & & & & \\
\hline & & $\mathrm{R}^{2} \mathrm{~T}=0,60$ & & & & \\
\hline & & $\mathrm{R}^{2} \mathrm{DN}=0,71$ & & & & \\
\hline & & $\mathrm{R}^{2} \mathrm{GD}=0,61$ & & & & \\
\hline
\end{tabular}

Yapılan yol analizi sonucunda, araştırma modeli kapsamında etkisi sorgulanan altı ilişkiden beşinin anlamlı olduğu görülmektedir. Sonuçlar özellikle algılanan kullanım kolaylığının önemini ortaya koymaktadır. Algılanan kullanım kolaylığının hem algılanan fayda $(\beta=0,767, p<0,001)$ hem de tutum $(\beta=0,268, p<0,001)$ üzerinde anlamlı ve pozitif bir etkisi olduğu görülmektedir. Böylece $\mathrm{H} 1$ ve $\mathrm{H} 3$ hipotezleri desteklenmektedir. Diğer taraftan algılanan faydanın tutumu $(\beta=0,548, \mathrm{p}<0,001)$ anlamlı ve pozitif bir şekilde etkilediği ancak davranışsal niyet üzerinde $(\beta=0,119, \mathrm{p}>0,001)$ anlamlı bir etkisi olmadığ bulgusuna ulaşılmaktadır. Bu nedenle $\mathrm{H} 2$ hipotezi desteklenirken, eldeki veriler 1şı̆̆ında $\mathrm{H} 4$ hipotezi reddedilmektedir. Son olarak; bulgular, tutumun davranışsal niyet $(\beta=0,752, p<$ $0,001)$ ve davranışsal niyetin gerçekleşen davranış $(\beta=0,782, \mathrm{p}<0,001)$ üzerinde anlamlı ve pozitif bir etkisini ortaya koyarak H5 ve H6 hipotezlerini desteklemektedir. Dolayısıyla model kapsamında sunulan doğrudan etkileri içeren beş hipotezin desteklendiği, birinin ise desteklenmediği söylenebilir.

Analiz sonucunda model tarafindan üretilen değerler arasında AF, T, DN ve GD açıklanma değerleri de bulunmaktadır. Bu kapsamda, araştırma modelinin 0,61 düzeyinde tüketicilerin gerçekleştirdikleri davranış olan online alışverişlerinde sanal kart kullanımını açıkladığı görülmektedir $\left(\mathrm{R}^{2} \mathrm{GD}=0,61\right)$.

\section{Sonuç ve Öneriler}

Araştırmada, TKM'ye dayalı olarak tüketicilerin sanal kart kullanımlarının gerçekleşmesinde; algılanan fayda, algılanan kullanım kolaylığı, tutum ve niyet faktörlerinin etkileri ortaya konulmaya çalışılarak internetten güvenle alışveriş yapılmasını sağlayacak sanal kart ödeme yöntemine ilişkin tüketicinin kabulü ve benimseme modeli ele alınmıştır. "Gerçekleşen davranış" olarak "tüketicilerin online alışverişlerinde sanal kart kullanımları", çalışmanın ulaşılmak istenen temel noktası olmuştur. Bu doğrultuda ele alınan çalışmada tüketicilerin sanal kart kullanımına direnç göstermeyip sistemi benimsemesi üzerinde etkili olacağ 1 öngörülen faktörler incelenmiştir. 
Yapılan analizler sonucunda, tüketicilerin sanal kart kullanımına ilişkin algıladığı kullanım kolaylı̆̆ının algıladığı fayda üzerinde pozitif ve anlamlı bir etkisi olduğu tespitine ulaşılmaktadır. Sanal kart kullanımının kolay/anlaşılır olması ve fazla çaba gerektirmemesi, online alışverişlerindeki ödeme işlemlerini tüketicilerin güvenle yapmasını sağladığını ve online alışveriş performansını arttırdığını göstermektedir. Diğer bir ifadeyle; sanal kart kullanımını kolay bulan tüketicilerin, sanal kart kullanımından daha fazla fayda elde ettiği sonucuna ulaşılabilmektedir. Öte yandan, algılanan kullanım kolaylığının ve algılanan faydanın, tüketicinin sanal kart kullanma isteğini ortaya çıkaran etkiler oluşturduğu görülmektedir. Öyle ki, sanal kart kullanımına ilişkin algılanan faydanın ve algılanan kullanım kolaylığının tutum üzerinde doğrudan ve olumlu etkisi olduğu görülmektedir. Dolayısıyla tüketiciler hem online alışverişlerinin güvenliğini sanal kart kullanarak kolayca sağlayabildikçe hem de ödeme işlemlerinin güvenliğini arttırmak için sanal kart kullanmayı faydalı buldukça, sanal kart kullanmanın gerekli ve doğru bir seçim olduğunu düşünmektedir. Özellikle tüketicilerin, sanal kart kullanımına (gerçekleşen davranış) kendilerini hazırladıkları bir eğilim sergilemelerinde algıladıkları faydanın, kullanım kolaylığına oranla daha yüksek derecede etkili olduğu da söylenebilmektedir.

Sanal kart kullanımının kolay ve faydalı olduğuna inanan tüketicinin, sanal kart kullanımına ilişkin pozitif bir tutum sergilediği görülürken; söz konusu tutumun da niyet üzerinde pozitif ve anlamlı bir etkisi olduğu tespitine ulaşılmaktadır. Böylelikle araştırmaya katılan tüketicilerin online alışverişlerinde sanal kart kullanımlarından dolayı memnuniyet duydukları ifade edilebilir. Tüketicilerin, sanal kart kullanımlarına ilişkin olumlu tepkilerinin, sanal kartı kullanma niyetleri üzerinde önemli ve yadsınamayacak düzeyde güçlü bir etki oluşturduğu söylenebilir. Dolayısıyla tüketicinin sanal kart kullanma çabasının ve isteminin şekillenmesi için tüketicide sanal karta ilişkin olumlu bir değerlendirme oluşması gerekmektedir. $\mathrm{Bu}$ noktada işletmelerin sanal kart kullanımını özendirme çabalarının yadsınamaz olduğu ifade edilebilir. Ancak algılanan faydanın sanal kart kullanımına devam etme niyeti üzerinde doğrudan anlamlı bir etkisine rastlanmamaktadır. $\mathrm{Bu}$ durum; tüketicilerin sanal kart kullanımlarının online alışveriş performanslarını arttırdığına ilişkin algılarının, sanal kartı kullanmak için sarf ettikleri çaba üzerinde doğrudan etkili olmadığını göstermektedir. Ancak öte yandan; sanal kart kullanımının kabulü için davranış niyeti üzerinde etkiye sahip olan tutuma ilişkin algılanan faydanın, yüksek bir tesir gücü olduğu da görülmektedir.

Sürecin, varılmak istenen son basamağı olan sanal kart kullanma davranışının (gerçekleşen davranış) kabulünde niyetin önemli bir öncül olduğu görülmektedir. Öyle ki, niyetin gerçekleşen davranış olan sanal kart kullanımı üzerinde doğrudan ve olumlu etkileri olduğunu çalışmanın bulguları ortaya koymaktadır. Dolayısıyla online alışverişlerinde sanal karta ilişkin tüketicilerde bir niyet oluştuysa, bunun sanal kartı kullanma davranışını oluşturacağı söylenebilmektedir. Dolayısıyla, online alışverişin güvenle yapılması konusunda kendilerine kullanım kolaylığı, açıklığı sağlayan ve alışveriş performansını yükselten sanal kart kullanımına ilişkin tüketicilerin pozitif değerlendirmelerinin ve kullanıma devam etme niyetlerinin, sanal kart kullanımlarının kabulünde etki oluşturan faktörler olarak değerlendirilebileceği ifade edilebilir.

Sanal kartı çıkaran kuruluşlar olan bankaların, sanal kartları kullanıcı dostu olacak şekilde sunmaları; online alışverişlerine ilişkin ödemelerini güvenli bir şekilde yapmak isteyen tüketicilerin, müşterisi olduklanı bankanın sanal kart kullanımına sıklıkla 
başvuracağını göstermektedir. Öte yandan online mağazaları üzerinden müşterilerinin güvenli bir şekilde alışveriş yapabilmeleri için üye işyerlerinin sanal kart ödeme yöntemine destek vermesinin gerektiği de açıktır. Bankalar ve üye işyerleri tarafından sanal kart ödeme yöntemine yapılacak yatırımlar, sistemi geliştirerek ve iyileştirerek müşteri memnuniyetini sağlayacak önemli stratejik bir unsur haline gelmektedir. Dolayısıyla tüketicilerin sanal kart kullanma davranışında bulunurken nelerden etkilendiğinin farkında olunması, endişelerinin bertaraf edilmesi ve beklentilerinin karşılanması, sektör için kaldıraç etkisi yaratacaktır. Böylelikle de günümüz iş dünyasında yaşanan yoğun rekabet karşısında sanal kart ödeme yöntemine yatırım yapan işletmelerin rakiplerine karş1 üstünlük sağlayabileceği öngörülmektedir. Bu sebepledir ki; hem bankaların hem de üye iş yerlerinin tüketicilerde sanal karta ilişkin farkındalık sağlamaları ve sanal kart kullanımını özendirmeleri teşvik edilebilir.

Gelecekte yapılacak çalışmalarda algılanan fayda ve algılanan kullanım kolaylığı üzerinde etkili olan dışsal değişkenlerin de araştırma modeline dâhil edilmesi ile sanal kart kullanımı üzerinde tüketicilere, sisteme ve işletmelere ilişkin dışsal değişkenlerin etkisi belirlenmeye çalışılarak hem literatüre hem de sektör uygulayıcılarına daha detaylı bilgiler sağlanacağı düşünülmektedir. Ayrıca sonraki çalışmaların, mevcut çalışmanın daha da üzerinde yüksek örneklem düzeyine ulaşmasının sağlanması; sonuçların daha da genellenebilir hale gelmesine imkân sağlayacak bir öneri olarak değerlendirilebilir. Son olarak, tüketicilerin sanal kart kullanımlarına ilişkin kabullerini etkileyen faktörlerin nitel olarak ele alınmasının daha derin ve zengin sonuçlara ulaşmak açısından literatüre katkı sağlayacağı düşünülmektedir.

\section{Kaynakça}

Adams, D. A, Nelson, R. R. ve Todd, P. A. (1992). Perceived Usefulness, Ease of Use, and Usage of Information Technology: A Replication. MIS Quarterly, 16 (2): 227-247.

Agarwal, R. ve Prasad, J. (1999). Are Individual Differences Germane to the Acceptance of New Information Technologies? Decision Sciences, 30 (2), 361-391.

Al-Somali, S. A., Gholami, R. ve Clegg, B. (2009). An Investigation into the Acceptance of Online Banking in Saudi Arabia. Technovation, 29 (2): 130-141.

Alharbi, S., \& Drew, S. (2014). Using the Technology Acceptance Model in Understanding Academics' Behavioural Intention to Use Learning Management Systems. International Journal of Advanced Computer Science and Applications, 5(1), 143-155.

Aras, M., Özdemir, Y. ve Bayraktaroğlu, S. (2015). İnsan Kaynakları Bilgi Sistemlerine Yönelik Algıların Teknoloji Kabul Modeli İle İncelenmesi. Ege Akademik Bakış, 15 (3): 343-351.

Arıkan, E., \& Telci, E. E. (2014). Marka Özgünlüğü ve Boyutlarının Müşteri Tutum ve Satın Alma Davranışı Üzerindeki Etkileri. Pazarlama ve Pazarlama Araştırmaları Dergisi, 7(14), 87-106.

Bagozzi, R. P., \& Yi, Y. (1988). On the Evaluation of Structural Equation Models. Journal of the Academy of Marketing Science, 16(1), 74-94.

Bankacılık Düzenleme ve Denetleme Kurulu (BDDK) (2018). https://www.bddk.org.tr/websitesi/turkce/kurum_bilgileri/SSS/16853sanal_kredi_karti_n edir_guvenli_midir.pdf (Erişim Tarihi: 12 Nisan 2018).

Bankacılık Düzenleme ve Denetleme Kurulu (BDDK) Tebliğ Taslağı (2016). https://www.bddk.org.tr/websitesi/turkce/mevzuat/duzenleme_taslaklari/13479karttebligi. pdf (Erişim Tarihi: 10 Nisan 2018). 
Bilgi Teknolojileri ve İletişim Kurumu (BTK) Pazar Verileri Raporu (2017). https://www.btk.gov.tr/uploads/pages/2017-q4.pdf (Erişim Tarihi: 3 Mart 2018).

Ceylan, H. H., Genç, E. ve Erem, I. (2013). Tüketicilerin İnternet Bankacıllı̆ıını Benimsemesini Etkileyen Faktörlerin Yapısal Eşitlik Modeli ile Araştırılması. Anadolu Üniversitesi Sosyal Bilimler Dergisi, 13 (3): 143-154.

Cheng, J. M. S., Sheen, G. J. ve Lou, G. C. (2006). Consumer Acceptance of the Internet as a Channel of Distribution in Taiwan - A Channel Function Perspective. Technovation, 26 (7): 856-864.

Cronin, J. J., Brady, M. K. ve Hult, G. T. M. (2000). Assessing the Effects of Quality, Value, and Customer Satisfaction on Consumer Behavioral Intentions in Service Environments. Journal of Retailing, 76 (2): 193-218.

Çelik, H. E., Yılmaz, V. ve Pazarlıoglu, V. (2010). Teknoloji Kabul Modeli ve Bir Uygulama. Finans Politik \& Ekonomik Yorumlar, 47 (540): 35-44.

Çivici, T. ve Kale, S. (2007). Mimari Tasarım Bürolarında Bilişim Teknolojilerinin Kullanımını Etkileyen Faktörler: Bir Yapısal Denklem Modeli. 4. İnşaat Yönetimi Kongresi Bildiriler Kitabl, İstanbul, Türkiye: 119-128.

Çokluk, Ö., Şekercioğlu, G. ve Büyüköztürk Ş. (2014). Sosyal Bilimler İçin Çok Değişkenli İstatistik: SPSS ve LISREL Uygulamaları, 3. Bask1, Ankara: Pegem Akademi.

Davis, F. D. (1985). A Technology Acceptance Model for Empirically Testing New EndUser Information Systems: Theory and Results. Massachusetts Institute of Technology, PhD Dissertation, MIT Sloan School of Management, Cambridge, MA.

Davis, F. D. (1989). Perceived Usefulness, Perceived Ease of Use, and User Acceptance of Information Technology. MIS Quarterly, 13 (3): 319-340.

Davis, F. D., Bagozzi, R. P. ve Warshaw, P. R. (1989). User Acceptance of Computer Technology: A Comparison of Two Theoretical Models. Management Science, 35 (8): 982-1003.

Dölarslan, E. Ş. ve Özer, A. (2014). Hizmet Kalitesi, Tatmin ve Güvenin Daha Fazla Ödeme Eğilimi Üzerindeki Etkileri. Anadolu Üniversitesi Sosyal Bilimler Dergisi, 14 (1): 31-58.

Durmuş, B., Yurtkoru, E. S., Çinko, M. (2013). Sosyal Bilimlerde SPSS'le Veri Analizi (5.Bask1). İstanbul: Beta.

Fishbein, M. A. ve Ajzen, I. (1975). Belief, Attitude, Intention and Behaviour: An Introduction to Theory and Research. Reading, MA: Addison-Wesley.

Gümüşsoy, Ç. A. ve Çalışır, F. (2009). E- Açık Eksiltme Teknolojisinin Kabulünü Etkileyen Faktörlerin Belirlenmesi. ITÜ̈ Dergisi/D Mühendislik, 8 (4): 107-118.

Gürbüz, S., \& Şahin, F. (2016). Sosyal Bilimlerde Araştırma Yöntemleri: Felsefe-YöntemAnaliz. 3. Baskı, Ankara: Seçkin Yayıncılık.

Ha, S. ve Stoel, L. (2009). Consumer E-Shopping Acceptance: Antecedents in a Technology Acceptance Model. Journal of Business Research, 62 (5): 565-571.

Hair, J.F., Black, W.C., Babin, B.J., Anderson, R.E. ve Tatham, R.L. (2006). Multivariate Data Analysis, 6th Edition, New Jersey: Pearson Prentice Hall.

Hung, S. Y. ve Chang, C. M. (2005). User Acceptance of WAP Services: Test of Competing Theories. Computer Standards \& Interfaces, 27 (4): 359-370.

Jeong, H. (2011). An Investigation of User Perceptions and Behavioral Intentions towards the E-Library. Library Collections, Acquisitions, \& Technical Services, 35 (2-3): 45-60.

Kayış, A. (2006). SPSS Uygulamalı Çok Değişkenli İstatistik Teknikleri, 2. Bask1, Ed. Kalaycı, Ş., Ankara: Asil Yayın Dağıtım.

Keller, C. (2005). Virtual Learning Environments: Three Implementation Perspectives. Learning, Media and Technology, 30 (3): 299-311. 
Kim, Y. G. ve Woo, E. (2016). Consumer Acceptance of a Quick Response (QR) Code for the Food Traceability System: Application of an Extended Technology Acceptance Model (TAM). Food Research International, 85: 266-272.

King, W. R. ve He, J. (2006). A Meta-Analysis of the Technology Acceptance Model. Information \& Management, 43 (6): 740-755.

Kurtuluş, K. (2010). Araştırma Yöntemleri, İstanbul: Türkmen Kitabevi.

Kurulgan, M. ve Özata, F. Z. (2010). Elektronik Kütüphane Hizmetlerinin Öğretim Elemanları Tarafından Benimsenmesinde Etkili Olan Faktörler: Anadolu Üniversitesi Öğretim Elemanları Üzerinde Bir Araştırma. Bilgi Dünyası, 11 (2): 243-262.

Kwok, D. ve Yang, S. (2017). Evaluating the Intention to Use ICT Collaborative Tools in a Social Constructivist Environment. International Journal of Educational Technology in Higher Education, 14 (1): 1-14.

Lee, M. C. (2009). Factors Influencing the Adoption of Internet Banking: An Integration of TAM and TPB with Perceived Risk and Perceived Benefit. Electronic Commerce Research and Applications, 8 (3): 130-141.

Lemay, D. J., Morin, M. M., Bazelais, P. ve Doleck, T. (2018). Modeling Students' Perceptions of Simulation-Based Learning Using the Technology Acceptance Model. Clinical Simulation in Nursing, 20: 28-37.

Malhotra, N. K. (2010). Marketing Research: An Applied Orientation. 6th Edition, New Jersey: Pearson Education Inc.

Moon, J. W. ve Kim, Y. G. (2001). Extending the TAM for a World-Wide-Web Context. Information \&Management, 38 (4): 217-230.

Munoz-Leiva, F., Climent-Climent, S. ve Liebana-Cabanillas. (2017). Determinants of Intention to use the Mobile Banking Apps: An Extension of the Classic TAM Model. Spanish Journal of Marketing, 21 (1): 25-38.

Özer, G., Özcan, M. ve Aktaş, S. (2010). Muhasebecilerin Bilgi Teknolojisi Kullanımının Teknoloji Kabul Modeli (TKM) İle İncelenmesi. Journal of Yaşar University, 5 (19): 3278-3293.

Park, N., Roman, R., Lee, S. ve Chung, J. E. (2009). User Acceptance of a Digital Library System in Developing Countries: An Application of the Technology Acceptance Model. International Journal of Information Management, 29 (3): 196-209.

Schermelleh-Engel, K.,Moosbrugger, H. ve Müller, H. (2003). Evaluating the Fit of Structural Equation Models: Tests of Significance and Descriptive Goodness-of-Fit Measures. Methods of Psychological Research Online, 8 (2): 23-74.

Şıklar, E., Tunalı, D. ve Gülcan, B. (2015). Mobil İnternet Kullanımının Benimsenmesinde Yakınsama Faktörüyle Teknoloji Kabul Modeli. Anadolu Üniversitesi Sosyal Bilimler Dergisi, 15 (2): 99-110.

Şimşek, Ö. F. (2007). Yapısal Eşitlik Modellemesine Giriş: Temel İlkeler ve LISREL Uygulamaları, Ankara: Ekinoks Yayıncılık.

Turan, A. H. (2008). İnternet Alışverişi Tüketici Davranışını Belirleyen Etmenler: Geliştirilmiş Teknoloji Kabul Modeli (E-TAM) ile Bir Model Önerisi. Akademik Bilişim 2008 Konferansı, Çanakkale Onsekiz Mart Üniversitesi, Çanakkale, Türkiye, 30 Ocak-01 Şubat 2018: 723-731.

Turan, B. ve Haşit, G. (2014). Teknoloji Kabul Modeli ve Sınıf Öğretmenleri Üzerinde Bir Uygulama. Uluslararası Alanya İşletme Fakültesi Dergisi, 6 (1): 109-119.

Tüfekci, Ö. K. (2014). Karekodların Pazarlama İletişimi Rolünü Teknoloji Kabul Modeli ile Açıklamaya Yönelik Bir Araştırma. Pamukkale Işsletme ve Bilişsim Yönetimi Dergisi, 1 (1): $36-52$. 
Uğur, N. G. ve Turan, A. H. (2016). Mobil Uygulama Kabul Modeli: Bir Ölçek Geliştirme Çalışması. Hacettepe Üniversitesi İktisadi ve İdari Bilimler Fakültesi Dergisi, 34 (4): 97126.

Ustasüleyman, T. ve Eyüboğlu, K. (2010). Bireylerin İnternet Bankacılığını Benimsemesini Etkileyen Faktörlerin Yapısal Eşitlik Modeli ile Belirlenmesi. BDDK Bankacılık ve Finansal Piyasalar, 4 (2): 11-38.

Venkatesh, V. (2000). Determinants of Perceived Ease of Use: Integrating Control, Intrinsic Motivation, and Emotion into the Technology Acceptance Model. Information Systems Research, 11 (4): 342-365.

Venkatesh V. ve Davis, F. D. (2000). A Theoretical Extension of the Technology Acceptance Model: Four Longitudinal Field Studies. Management Science, 46 (2), 186204.

Vijayasarathy, L. R. (2004). Predicting Consumer Intentions to Use On-Line Shopping: The Case for an Augmented Technology Acceptance Model. Information \& Management, 41 (6): 747-762.

Wu, M. Y. ve Liao, S. C. (2011). Consumers' Behavioral Intention to Use Internet Shopping: An Integrated Model of TAM and TRA. Journal of Statistics and Management Systems, 14 (2): 375-392.

Wu, J. H. ve Wang, S. C. (2005). What Drives Mobile Commerce? An Empirical Evaluation of the Revised Technology Acceptance Model. Information \& Management, 42 (5), 719 729.

Yaşlıŏlu, M. M. (2017). Sosyal Bilimlerde Faktör Analizi ve Geçerlilik: Keşfedici ve Doğrulayıcı Faktör Analizlerinin Kullanılması. İstanbul Üniversitesi İşletme Fakültesi Dergisi, 46 (Özel Sayı), 74-85.

Yılmaz, C. ve Tümtürk, A. (2015). İnternet Üzerinden Alışveriş Niyetini Etkileyen Faktörlerin Genişletilmiş Teknoloji Kabul Modeli Kullanarak İncelenmesi ve Bir Model Önerisi. Yönetim ve Ekonomi, 22 (2): 355-384.

Yoon, H. Y. (2016). User Acceptance of Mobile Library Applications in Academic Libraries: An Application of the Technology Acceptance Model. The Journal of Academic Librarianship, 42 (6): 687-693. 


\section{Ek: Ölçekler}

\begin{tabular}{|c|c|c|c|}
\hline Faktör & İfadeler & Kisaltmalar & Ölçek Tipi \\
\hline \multirow{4}{*}{$\begin{array}{l}\text { Algilanan } \\
\text { Fayda } \\
\text { (AF) }\end{array}$} & $\begin{array}{l}\text { Güvenilir bir bankacılık ürünü olan sanal kartı } \\
\text { kullanmak online alışveriş performansımı } \\
\text { arttırır. }\end{array}$ & AF1 & \multirow{4}{*}{$\begin{array}{l}\text { 1= Kesinlikle } \\
\text { Kat1lmiyorum } \\
\text { 5= Kesinlikle } \\
\text { Katıliyorum }\end{array}$} \\
\hline & $\begin{array}{l}\text { Sanal kart kullanmak online alışverişlerde } \\
\text { endişemi azaltarak güvenli ve hızlı alışveriş } \\
\text { yapma deneyimi sağlar. }\end{array}$ & $\mathrm{AF} 2$ & \\
\hline & $\begin{array}{l}\text { Sanal kart, online alışverişlerimde yaptığım } \\
\text { ödeme işlemlerinin güvenliğini sağlar. }\end{array}$ & AF3 & \\
\hline & $\begin{array}{l}\text { Online alışverişlerde, ödeme } \\
\text { güvenliğininin arttırılması için } \\
\text { kullanmayı faydalı buluyorum. }\end{array}$ & AF4 & \\
\hline \multirow{4}{*}{$\begin{array}{c}\text { Algilanan } \\
\text { Kullanım } \\
\text { Kolaylığı } \\
\text { (AKK) }\end{array}$} & $\begin{array}{l}\text { Online alışverişlerimde sanal kart kullanmak } \\
\text { oldukça açık ve anlaşılırdır. }\end{array}$ & AKK1 & \multirow{4}{*}{$\begin{array}{c}\text { 1= Kesinlikle } \\
\text { Katılmiyorum } \\
\text { 5= Kesinlikle } \\
\text { Katıliyorum }\end{array}$} \\
\hline & $\begin{array}{l}\text { Online alışverişlerimde sanal kart kullanmak } \\
\text { çok fazla zihinsel çaba gerektirmez. }\end{array}$ & AKK2 & \\
\hline & $\begin{array}{l}\text { Online alışverişlerimde sanal kart kullanmak } \\
\text { kolaydır. }\end{array}$ & AKK3 & \\
\hline & $\begin{array}{l}\text { Online alışveriş̧lerimin güvenliğini, sanal kart } \\
\text { kullanarak kolayca sağlayabilirim. }\end{array}$ & AKK4 & \\
\hline \multirow{3}{*}{$\begin{array}{l}\text { Tutum } \\
\text { (T) }\end{array}$} & $\begin{array}{l}\text { Online alışveriş̧lerimde sanal kart kullanmanın } \\
\text { doğru bir düşünce olduğuna inanıyorum. }\end{array}$ & $\mathrm{T} 1$ & \multirow{3}{*}{$\begin{array}{c}\text { 1= Kesinlikle } \\
\text { Katılmiyorum } \\
5=\text { Kesinlikle } \\
\text { Kat1liyorum }\end{array}$} \\
\hline & 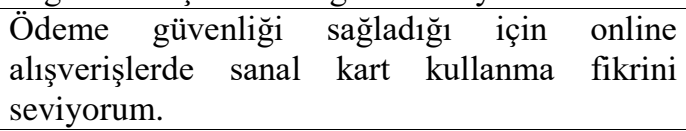 & $\mathrm{T} 2$ & \\
\hline & $\begin{array}{l}\text { Online alışverişlerimde sanal kart kullanmanın } \\
\text { gerekli bir seçim olduğunu düşünüyorum. }\end{array}$ & T3 & \\
\hline \multirow{3}{*}{$\begin{array}{l}\text { Davranışsal } \\
\text { Niyet } \\
\text { (DN) }\end{array}$} & $\begin{array}{l}\text { Online alışverişlerimde sanal kartı, büyük } \\
\text { ihtimalle kullanmaya devam edeceğim. }\end{array}$ & DN1 & \multirow{3}{*}{$\begin{array}{c}\text { 1= Kesinlikle } \\
\text { Kat1lmiyorum } \\
\text { 5= Kesinlikle } \\
\text { Kat1liyorum }\end{array}$} \\
\hline & $\begin{array}{l}\text { Online alışverişlerine ilişkin güvenli ödeme } \\
\text { yapabilmeleri için sanal kart kullanmalarını } \\
\text { arkadaşlarıma tavsiye edeceğim. }\end{array}$ & DN2 & \\
\hline & $\begin{array}{l}\text { Online alışverişlerimdeki ödeme işlemlerimin } \\
\text { güvenliğine ilişkin bir seçim yapmak zorunda } \\
\text { kalırsam yine sanal kart kullanmayı tercih } \\
\text { ederim. }\end{array}$ & DN3 & \\
\hline \multirow{2}{*}{$\begin{array}{l}\text { Gerçekleşen } \\
\text { Davranış } \\
\text { (GD) }\end{array}$} & $\begin{array}{l}\text { Online alışverişlerimi güvenle yapabilmek için } \\
\text { sanal kartı sık kullanırım. }\end{array}$ & GD1 & \multirow{2}{*}{$\begin{array}{c}\text { 1= Kesinlikle } \\
\text { Katılmiyorum } \\
\text { 5= Kesinlikle } \\
\text { Kat1liyorum }\end{array}$} \\
\hline & $\begin{array}{l}\text { Online alışverişlerimi güvenle yapabilmek için } \\
\text { sanal kartı çok sık kullanırım. }\end{array}$ & GD2 & \\
\hline
\end{tabular}

